\title{
Development of human capital in institutions from the Polish financial sector: Towards new technologies and agile business models
}

\author{
Tadeusz A. Grzeszczyk
}

\begin{tabular}{|c|c|}
\hline \multicolumn{2}{|r|}{ A B S T R A C T } \\
\hline \multicolumn{2}{|c|}{$\begin{array}{l}\text { Objective: The objective of this paper is to present challenges associated with human } \\
\text { capital development and need to be addressed in order to improve the effectiveness } \\
\text { of implementation of new technologies and agile business models in institutions from } \\
\text { the Polish financial sector. }\end{array}$} \\
\hline \multicolumn{2}{|c|}{$\begin{array}{l}\text { Research Design \& Methods: The study utilizes both qualitative and quantitative re- } \\
\text { search methods: critical literature review, non-participant observation, unstructured } \\
\text { interviews, statistical data analysis and comparative research. }\end{array}$} \\
\hline \multicolumn{2}{|c|}{$\begin{array}{l}\text { Findings: It was determined how employees of the financial sector are motivated by } \\
\text { means of remuneration and what challenges are to be addressed that are associated with } \\
\text { implementation of new technologies and agile business models in banking institutions. }\end{array}$} \\
\hline \multicolumn{2}{|c|}{$\begin{array}{l}\text { Contribution \& Value Added: The needs for developing objectively verifiable criteria } \\
\text { for assessing the success of Al projects and agile models implementation as well as a } \\
\text { lack of knowledge about the real benefits of such projects and models resulting from } \\
\text { small expenditures on training of employees have been identified. }\end{array}$} \\
\hline Article type: & search paper \\
\hline Keywords: & \\
\hline & \\
\hline & \\
\hline
\end{tabular}

\section{Suggested citation:}

Grzeszczyk, T. (2020). Development of human capital in institutions from the Polish financial sector: Towards new technologies and agile business models. International Entrepreneurship Review (previously published as International Entrepreneurship / Przedsiębiorczość Międzynarodowa), 6(4), 5163. https://doi.org/10.15678/IER.2020.0604.04

\section{INTRODUCTION}

Regardless of the dynamic development of information technologies (ITs) supporting the functioning of financial institutions and an increase in the number of investments in infor- 
mation and communication technologies (ICTs) and artificial intelligence (AI) projects, one should remember about human capital, which is the most valuable element of any organization. In the face of growing competition and professionalism, it is necessary to take care of human resources development and incur considerable costs. Digital consumers of financial services, regardless of the need to quickly and relatively easily settle their tasks via ICT devices also require contact with human employees, not just avatars. This is often difficult for the decision-maker to accept because employing a large number of experts and specialists represents a significant proportion of costs borne by financial institutions. Simple restructuring based on reducing employment in bank branches and wider introduction of increasingly sophisticated ICT solutions have their limitations.

Polish employees are characterized by one of the lowest participation rates in various lifelong learning systems in Europe(Eurostat, 2019). Expenditures on education, improvement and retraining of personnel are insufficient. Research conducted in other countries shows that the level of documented education of financial institutions employees has little impact on the effects of their work, while continuous professional training clearly positively affects the growth of their productivity as well as performance, and is necessary for proper human capital development (Khan et al., 2014).

It is important to note the need to increase support for human capital development in the Polish financial institutions. The main research question is as follows: what are the challenges (associated with human capital development) that need to be addressed in order to improve the effectiveness of implementation of new technologies and agile business models in institutions from the Polish financial sector? The search for answers to this question is facilitated by the formulation of three sub-questions that guide the empirical research, i.e.:

- what are opinions of the bank employees about the challenges related to the implementation of new technologies and agile business models in financial institutions?

- are employees of the Polish financial sector properly motivated by remuneration to take on these challenges?

- are the expenditures on developing human capital through training, improvement and retraining of employees at an appropriate level?

In addition to this introduction, next sections include the literature review and presentation of materials and methods applied in the research. The final sections describe achieved results, discussion and in the last one there are conclusions.

\section{LITERATURE REVIEW}

In the digital era, advanced economies are supported by knowledge management processes and the development of human capital in financial and nonfinancial institutions (Clarke \& Gholamshahi, 2018). Many studies have demonstrated the relationship between knowledge management, education, human capital management and economic growth with fostering socioeconomic prosperity at micro and macroeconomic levels (e.g. GarzaRodriguez et al., 2018; Mansion \& Bausch, 2019). Information, e-knowledge as well as intellectual and brainpower activity together build key economic resources of modern financial institutions (Hafizi \& Zawiyah, 2009). Their success depends on this kind of resources and human capital which concerns the competences of employees in organizations and human resources of cooperating external entities. 
Due to the fact that the role of employees in all types of organizations can be treated from the point of view of their resources, the terms 'human resources' and 'human capital' are often used interchangeably (Osranek \& Zink, 2014). The first term is more traditional, while the second term is more precise (especially for financial institutions) because it clearly indicates the financial benefits of knowledge related to employees.

Human capital approach is not yet widely accepted in environments related to the financial sector. It can often be found in academic considerations and scientific publications. Some argue that in the past, aversion to this approach sometimes resulted from suspicions of treating people as machines (Becker, 2009). In this case, the term human resources' is even more associated with it.

Human capital has its own specificity, e.g. it is not tradable (unlike structural capital), it is not owned by institutions employing personnel, because it is the result of the work of minds and depends on the skills of individual employees and the professional knowledge they generate (Shih et al., 2010). Literature analyzes concerning this capital are therefore usually conducted on two levels: individual or organizational (Buzavaite \& Korsakiene, 2019). The right approach to human capital management and application of knowledge-based solutions ensure sustainable development of financial institutions, achieving high added value and reaching a constant strategic advantage on the market. Bibliometric analysis of two key concepts of 'human capital' and 'social capital', combination of these concepts and their relationship with sustainability are available in the literature (Garrigos-Simon et al., 2018).

Institutions from financial sector, e.g., banks, credit unions, investment institutions, insurance companies, mutual funds, intermediate in the cooperation of household and corporate sectors. They perform simultaneously or separately the following two functions: brokerage function (agents providing information for transfer of services and transaction services) as well as asset transformation function i.e. purchasing equities, bonds, debts - claims called primary securities and selling financial claims in the form of deposits, insurance policies etc. (Saunders \& Cornett, 2007). Bearing in mind these aspects, it seems obvious expenditures on the development of knowledge and human capital are necessary in order to achieve measurable economic benefits of financial institutions, and the source of this type of key capital is systematically educated and trained employees. Investments in human capital as well as an individual's education and training are analogous to business investments in equipment and fixed assets (Becker, 2009). Necessary investment in employment and development of human capital can be discouraging, therefore simple solutions such as reduction of employment arise. However, human capital is a key factor in building competitive advantage and achieving right position on the local and global market. Financial institutions are, above all, social systems in which the importance of human capital is particularly significant.

Financial institutions have knowledge-intense and intellectually-intense character and they do not rely on physical resources but on intangible ones (Mavridis, 2004; Yao et al., 2019). The development, operational success and sustainability of the financial sector are not based on tangible assets, but on human and intellectual capital, as well as on such elements as advanced systems, processes, expertise, supportive culture, skills, knowledge, information and specific environment (Haris et al., 2019). 
Human capital is a set of the following elements: knowledge resulting from experience, creativity, social and personality attributes, which together determine the ability to perform tasks leading to the generation of economic value (Goldin, 2016).In every organization, the development of human capital requires increasing outlays and, consequently, increasing labour costs. The development of human capital can be based on improving employees' qualifications, e.g. by organizing training, which usually leads to an increase in their effectiveness as well as efficiency, and is also a strategic factor of the success of financial institutions. This kind of development also contributes to improving the intellectual capital of the organization, which includes total knowledge in the organization providing it with a competitive edge, knowledge, experience, intellectual property, data and information that can be used together to create new value (Dumay, 2016).

Intellectual capital is classified in various ways and it is sometimes referred to as human capital supplemented by structural capital, however, more often it is described as the sum of three types of capital: human, social and organizational (Subramaniam \& Youndt, 2005). Research on intellectual and human capital available in the literature is mainly carried out in the following three areas: determinants of disclosure, identification and valuation as well as international reporting comparisons (Bryl \& Truskolaski, 2017). Development of these capitals in institutions from financial sector, among others, can be achieved by incurring expenses related to raising professional qualifications, training, education, encouraging greater activity and innovation of employees. Therefore, it is necessary to reserve funds for this purpose at an appropriate level as part of labour costs, because it determines the survival and achieving the right competitive position of the organization on the market.

As a result of dynamic technological progress, turbulent changes in the environment, introduced innovations in IT processes and systems, the requirements for modern financial institutions are constantly elevated and it is increasingly difficult to deal with growing competition in this sector (Joshi et al., 2010). The strategy proposed by the European Commission is an expression of support for the successful shaping of the digital future based on big data and Al technologies, which will be introduced in small and large enterprises in the coming years, taking into account the principles of a fair and competitive economy, open, democratic and sustainable society as well as people's needs (European Commission, 2020).The development of Al and ICT technologies cannot mean giving up on noticing the key importance of human capital in financial institutions, in which people play a fundamental role and by using knowledge resources and financial means support the achievement of the goals of their organizations. Attaining these goals and building a competitive advantage is mainly associated with the development of human capital, for which (in the Polish financial sector) more funds should be allocated than at present.

Economic studies covering long periods of time prove that the introduction of new technologies (including ICT) does not reduce the number of jobs (e.g. in banking) but contributes to the increase in requirements for employees' knowledge and qualifications (Acemoglu \& Restrepo, 2016). Properly remunerated and motivated employees willingly use the opportunities provided by IT systems and do not treat them as competition. It cannot be said that people are slowly becoming redundant and are being replaced by computers. Employee participation in financial institutions and the human capital built thanks to them are essential. IT devices can replace people only when car- 
rying out relatively simple tasks such as withdrawing money from automated teller machines. Highly qualified specialists are needed to ensure relationship banking in modern institutions (Autor, 2015). The introduction of new ICT technologies on a large scale eliminates staff who are less educated, perform routine tasks (associated with repetitive and codifiable activities) and are poorly motivated (Bosio \& Cristini, 2018).

Motivating (in other words: leading) is one of the most important functions of classical organization management and one of the key factors contributing to the effective and efficient use of employees' skills and knowledge in human capital management. This management function should, of course, be analysed on a multifaceted basis, but in some situations, to simplify the demonstrative considerations, incentives can be reduced only to remuneration of employees in cash in accordance with traditional approaches (Griffin, 2018). These remuneration and related employee costs play an important role in the financial results of financial institutions.

Thus, it is worth looking at (based on statistical data) how employees of the financial sector are motivated by means of remuneration, how the labour costs of employees in Polish financial institutions are presented, and what are the important elements in the structure of the labour costs of these institutions. It is also necessary to know the results of research on the training participation rate of employees from various European countries and key literature items in this field (Danvila-del-Valle et al., 2019).

\section{MATERIAL AND METHODS}

The scope of considerations concerns mainly the institutions dealing in financial and insurance activities. During the study, research methods appropriate to the discipline of management sciences were used in order to support the collection and analysis of quantitative and qualitative data. The research process applied critical literature review, non-participant observation, unstructured interviews, statistical data analysis and comparative study. This type of literature review was chosen because it allows for a thorough reading of the publications, conducting comparative analyses and their assessments carried out from different research perspectives.

Observation was used to support the preparation of a qualitative description of the phenomena studied and their interpretation consistent with the context and specificity of human capital management in institutions from Polish financial sector.

The search for answers to the three research questions guides empirical research. The interviews assisted in seeking answers to the following first question: what are the opinions of bank employees on the challenges related to the implementation of new technologies and agile business models in financial institutions? Unstructured interviews conducted among several randomly selected employees of Polish banks in October and November 2019 were used to elicit their opinions, wishes, views, attitudes, experiences and openness to implement new technologies and agile business models in the financial sector. The second research question - are employees of the Polish financial sector adequately motivated by remuneration to take on these challenges - is what drives quantitative analyses, the implementation of which was based on data from public information systems at national level named Statistics Poland (formerly known as the Central Statistical Office). The third question - are the expenditures on developing human capital through training, improvement and retraining of employees at an appropriate level - is related not only to analyses based on data 
from Statistics Poland, but also to a comparative analysis taking into account other European countries and data from European Statistical Office (Eurostat).

\section{RESULTS}

Searching for an answer to the first research question, unstructured interviews were conducted among employees from various Polish banks focused on challenges related to their openness to implementation of new technologies and agile business models. Among the tasks requiring a solution, they primarily highlighted the needs for developing objectively verifiable indicators and criteria for assessing the success of IT and Al projects planned to be implemented as well as reliable estimation of the effects of implementing agile business models. The interviewees expressed anxiety about the possibilities of modernizing traditional organizational structures and pointed to the need for strong involvement of the management board and the HR department. They emphasized the fear of managers making important decisions about incorporating agile principles into the organization's strategy. Among the potentially available solutions, they suggested modifying the business strategy, including change agents in the board (responsible for implementing IT and AI projects), providing support of HR departments for the processes of introducing technological changes, cross-functional teams as well as agile and innovative solutions. Interviewees pointed out that not everyone knows the real benefits of implementing new Al technologies and agile business models. They reminded that there was a lack of training in this field financed by employers, who often emphasize the high labour costs incurred.

Then, in connection with the second research question, statistical data was collected on whether employees of the Polish financial sector are adequately motivated by remuneration to take on the challenges of effective implementation of new technologies and agile business models. Apparently, the diversity of labour costs results from the type and size of financial institutions (Table 1).

Table 1. The average monthly labour cost (in PLN) per one employee in Polish financial institutions for the private and public sectors

\begin{tabular}{|l|l|l|l|l|l|l|}
\hline \multirow{2}{*}{ Specification } & \multicolumn{3}{c|}{ Public Sector } & \multicolumn{3}{c|}{ Private Sector } \\
\cline { 2 - 8 } & Total & $\begin{array}{c}\text { More than } \\
\mathbf{4 9} \\
\text { employees }\end{array}$ & $\begin{array}{c}\text { From 10 } \\
\text { to 49 } \\
\text { employees }\end{array}$ & Total & $\begin{array}{c}\text { More than } \\
\mathbf{4 9} \\
\text { employees }\end{array}$ & $\begin{array}{c}\text { From 10 } \\
\text { to 49 } \\
\text { employees }\end{array}$ \\
\hline $\begin{array}{l}\text { Financial and insurance } \\
\text { activities }\end{array}$ & 9157 & 9155 & 9241 & 8233 & 8394 & 7101 \\
\hline Financial service activities & 8895 & 8905 & 8586 & 8186 & 8331 & 7173 \\
\hline $\begin{array}{l}\text { Insurance, reinsurance } \\
\text { and pension funding }\end{array}$ & 9487 & 9487 & No data & 9238 & 9148 & 14572 \\
\hline $\begin{array}{l}\text { Activities supporting } \\
\text { financial services as well } \\
\text { as insurance and pension } \\
\text { funds }\end{array}$ & 14798 & 14827 & 14573 & 7818 & 8152 & 6429 \\
\hline
\end{tabular}

Source: (Central Statistical Office, 2017). 
The third research question drove the collection of data from the Statistics Poland on expenditure on human capital development through training, improvement and retraining of employees (Table 2). Data from the Eurostat were collected for the purposes of comparative analyses.

Table 2. Selected components (in \%) in the structure of labour costs in financial institutions

\begin{tabular}{|c|c|c|c|c|c|c|}
\hline Specification & Total & $\begin{array}{c}\text { More than } \\
\mathbf{4 9} \text { em- } \\
\text { ployees }\end{array}$ & $\begin{array}{c}\text { From 10 } \\
\text { to 49 em- } \\
\text { ployees }\end{array}$ & Total & $\begin{array}{c}\text { More than } \\
\mathbf{4 9} \text { em- } \\
\text { ployees }\end{array}$ & $\begin{array}{c}\text { From } 10 \\
\text { to 49 em- } \\
\text { ployees }\end{array}$ \\
\hline $\begin{array}{c}\text { Total personal wages and } \\
\text { salaries }\end{array}$ & 79.9 & 80.0 & 77.7 & 82.0 & 81.9 & 82.5 \\
\hline $\begin{array}{c}\text { Retirement, pension and } \\
\text { insurance contributions } \\
\text { paid by employer }\end{array}$ & 13.3 & 13.3 & 14.4 & 13.9 & 14.0 & 13.6 \\
\hline $\begin{array}{c}\text { Expenditures on training, } \\
\text { improvement and retraining } \\
\text { of employees }\end{array}$ & 0.8 & 0.8 & 0.2 & 0.6 & 0.6 & 0.4 \\
\hline
\end{tabular}

Source: (Central Statistical Office, 2017).

The statistical data presented in Table 3 allow for comparative analyses of adult education in selected European countries.

Table 3. Adult learning in selected European countries (in \%)

\begin{tabular}{|l|c|c|c|c|c|c|}
\hline \multirow{2}{*}{ Country } & \multicolumn{2}{|c|}{ Total } & \multicolumn{2}{c|}{ Male } & \multicolumn{2}{c|}{ Female } \\
\cline { 2 - 7 } & $\mathbf{2 0 1 3}$ & $\mathbf{2 0 1 8}$ & $\mathbf{2 0 1 3}$ & $\mathbf{2 0 1 8}$ & $\mathbf{2 0 1 3}$ & $\mathbf{2 0 1 8}$ \\
\hline EU & 10.7 & 11.1 & 9.7 & 10.1 & 11.6 & 12.1 \\
\hline Switzerland & 29.3 & 31.6 & 30.0 & 32.4 & 28.7 & 30.9 \\
\hline Sweden & 28.4 & 29.2 & 21.5 & 22.4 & 35.5 & 36.1 \\
\hline Finland & 24.9 & 28.5 & 21.1 & 24.7 & 28.8 & 32.4 \\
\hline Estonia & 12.6 & 19.7 & 9.8 & 16.2 & 15.3 & 23.2 \\
\hline Netherlands & 17.9 & 19.1 & 17.4 & 18.3 & 18.4 & 20.0 \\
\hline Austria & 14.1 & 15.1 & 12.8 & 13.7 & 15.4 & 16.5 \\
\hline Portugal & 9.7 & 10.3 & 9.3 & 9.8 & 10.1 & 10.8 \\
\hline Germany & 7.9 & 8.2 & 7.9 & 8.5 & 7.9 & 8.0 \\
\hline Italy & 6.2 & 8.1 & 5.8 & 7.6 & 6.5 & 8.6 \\
\hline Cyprus & 7.2 & 6.7 & 7.0 & 6.8 & 7.4 & 6.6 \\
\hline Latvia & 6.8 & 6.7 & 5.1 & 4.8 & 8.2 & 8.4 \\
\hline Lithuania & 5.9 & 6.6 & 5.2 & 4.9 & 6.5 & 8.3 \\
\hline Poland & 4.3 & 5.7 & 3.8 & 5.1 & 4.9 & 6.3 \\
\hline Greece & 3.2 & 4.5 & 3.3 & 4.5 & 3.1 & 4.5 \\
\hline Slovakia & 3.1 & 4.0 & 2.9 & 4.2 & 3.3 & 3.8 \\
\hline Montenegro & 2.8 & 3.2 & 2.7 & 3.3 & 2.8 & 3.0 \\
\hline Croatia & 3.1 & 2.9 & 3.0 & 2.4 & 3.3 & 3.4 \\
\hline Bulgaria & 2.0 & 2.5 & 1.9 & 2.4 & 2.1 & 2.6 \\
\hline Romania & 2.0 & 0.9 & 2.2 & 1.0 & 1.8 & 0.9 \\
\hline
\end{tabular}

Source: (Eurostat, 2019). 
The indicator of adult education is determined by dividing the number of positive responses of people of the said age to the question about their participation in training (during the four weeks preceding the study) by the total number of people in the same age group (for Poland it is $5.7 \%$ in 2018).

\section{DISCUSSION}

The discussion is structured according to the research questions posed. Regarding the first research question concerning opinions of bank employees, they mainly indicated the need to develop objectively verifiable criteria for assessing the success of Al projects and the implementation of agile models, as well as the lack of knowledge about the real benefits of such projects and models resulting from small expenditure on employee training.

The statistical data collected in connection with the question concerning the appropriate remuneration motivation to take up the challenges allow for the formulation of positive answers. The total labour costs include: remuneration for work performed and for the time of not performing work, all bonuses, social security and health insurance, social benefits, as well as other costs incurred by the employer, such as payments in nature, meals, work clothes, service housing, employee transport, recruitment costs and taxes that are also labour costs. Such costs are fundamentally different depending on the type of ownership sector. In public sector units, they are higher compared to the private sector, e.g., in 2016, in the public sector labour costs related to the employment of one employee were 7.3\% higher compared to the private sector (Central Statistical Office, 2017).

In 2018, in Polish banks, employee costs amounted to almost PLN 17 billion, which represents $50.8 \%$ of their administrative costs. In comparison with 2017 , the $1.2 \%$ increase was mainly due to an increase in remuneration for employment contracts (Statistics Poland, 2019). These data confirm that labour and overhead costs have a significant share in the bank budget and therefore play a key role in shaping financial efficiency in institutions from the Polish financial sector. Labour costs vary considerably depending on the given branch of the national economy - the highest labour costs (average monthly labour cost per one employee in 2016) occur in information and communication branch (PLN 9356) as well as mining and quarrying branch (PLN 8967). In turn, consistently for several years, the lowest costs occur in accommodation and catering activities (PLN 3675).

Traditionally, there is some dissatisfaction among entrepreneurs in Poland associated with, in their opinion, high labour costs representing the total costs they incur in connection with hiring employees. They have seen significant increases in these costs over recent years. Still, unit labour costs are markedly lower than the EU average. This situation is used by international investment companies, which often locate outsourcing centres of financial sector services in Poland. Despite the use of automated financial processes, the demand for highly qualified and professional staff does not decrease. A significant challenge facing the Polish financial sector in this context is the current dynamic increase in wages, which in the next few years may cause a significant reduction in the distance in relation not only to the EU average, but also to more prosperous countries. It is not known whether in the future international investment companies will not start moving their outsourcing centres to poorer countries with lower labour costs.

Institutions related to financial and insurance activities have one of the highest labour costs (PLN 8415 PLN), and have been recording relatively high dynamics of labour costs for 
years (e.g. in the period 2012-2016, increase of about $12 \%$ in the average monthly cost per one employee) (Central Statistical Office, 2017).

The collected data proves that the diversity of labour costs results from the type and size of financial institutions. Previous studies (Grzeszczyk, 2017) showed that labour costs in large organizations exceed those in medium and small organizations, which was caused by the different pay systems, various approaches to the payment of any allowances, bonuses and overtime pay. In recent years, there has been an improvement in the labour market, a decrease in unemployment, an overall increase in wages and better treatment of employees. Labour costs in public institutions were still usually higher than in private ones. Due to the pandemic, employment conditions can be expected to deteriorate in 2020, and sometimes the statements of banking managers indicate that they miss the times when employers dictated employment conditions to a greater extent. The current negative changes on the labour market usually do not relate to the employment of IT specialists and many employees treat it as an opportunity to raise their qualifications in the field of new big data and Al technologies, and even to change their present profession to a more related to this area.

A significant increase in the average monthly labour cost per one employee in Polish financial institutions also results from the need to attract highly qualified specialists in the fields of ICT and Al. At the same time, reductions in less qualified personnel employed in branches of various banks from public and private sector can be observed. Laying off these less-paid employees does not compensate for the increase in salaries of the best IT specialists. The increase in their wages is additionally accompanied by the emergence of new foreign financial and consulting institutions on the Polish market that offer higher wages wishing to attract the best employees. This trend related to the increase in the requirements regarding the qualifications held by staff in human capital management is likely to persist and it is difficult to indicate the reasons for its inhibition.

After collecting statistical data and conducting comparative analyses, it is not possible to provide a positive answer to the third research question regarding the level of expenditure on human capital development through training, improvement and retraining of employees. The research conducted by Eurostat among 37 European countries shows that Polish employees aged 25-64 are characterized by a low value of participation indicator in various lifelong learning systems (Eurostat, 2019). In Polish financial institutions, the costs associated with the development of human capital are still insufficient. For example, expenditures on training, development and retraining of employees do not exceed $0.6-0.8 \%$ of total labour costs. In the case of private organizations, the share of this type of expenditure in labour costs is usually lower compared to institutions in the public sector. In small institutions (from private and public sector) it is usually the worst, and employees are forced to obtain the necessary qualifications and skills on their own.

The importance of human capital in financial institutions is visible, regardless of the ICT and AI technologies being developed and their increasingly better applications in banking. Appropriate management of this capital is one of the most crucial factors of sustainable development. People using knowledge resources are the basis for the functioning of these institutions and, above all, thanks to them, it is possible to achieve the organization's goals in an efficient and effective manner. The knowledge and competences of employees of financial institutions determine the ability of this type of organization to transform financial capital into services characterized by high cost-effectiveness and adequate quality. 
Appropriate human capital management can also contribute to achieving the desired competitive position. Therefore, it is necessary to allocate more funds to its development than at present. Employees should be encouraged to acquire knowledge, qualifications and skills, and be motivated by allocating funds for training to improve professional skills. The presented research results show that expenditure on human capital development in Polish financial institutions is far too low, and the adult learning rate is generally too low for post-socialist Central and Eastern European countries (except Estonia). It also has a broader meaning associated with developing the intellectual background for socio-economic growth in such countries. Empirical research shows that the basis of socio-economic growth of lower-middle-income countries is proper education, and the main factors determining successful development in social and economic fields are knowledge, erudition, intelligence, creativity, emotions and system thinking of people (Kuzkin et al., 2019).

In addition to increasing expenditures on training and improving human capital, it is desirable to create conditions in the environment of financial institutions conducive to its development. Currently, there are no proper tax breaks granted to employers in the case of expenses related to education and raising qualifications by their employees. In the longer term, such reliefs may bring benefits not only for financial institutions, but also increase funds allocated to, e.g., state social programs. Due to the fact that people participating in lifelong learning systems become more creative, productive and can help their organizations more in obtaining higher revenues from invested capital, as a result they contribute to increasing budget revenues from taxes. Therefore, it is worth proposing appropriate legal regulations supporting the activities of financial institutions related to bearing the costs of human capital development.

\section{CONCLUSIONS}

The article presents the challenges related to the development of human capital that should be taken in order to improve the effectiveness of implementing new technologies and agile business models in institutions from the Polish financial sector. Using both qualitative and quantitative research methods, it was determined how employees in the financial sector are motivated by remuneration and what the main challenges in this field are for them. First of all, the need to develop objectively verifiable criteria for assessing the success of Al projects and the implementation of agile models was identified, as well as a lack of knowledge about the real benefits of such projects and models resulting from low expenditure on employee training.

The results of this type of research can be used to improve the personnel strategy as an important element of human capital management processes in financial institutions. Properly qualified and motivated employees can significantly contribute to achieving the goals of organizations of strategic importance and be a determinant of their competitiveness. Increasing expenditures on employee education may not only improve the current efficiency of financial institutions, but also increase their long-term strategic potential.

It is necessary to have adequate human capital management in institutions from the Polish financial sector and to allocate larger funds focused on education and improving qualifications of employees, in accordance with the requirements arising from the agile implementation of advanced ICT and Al projects. Currently, there are times of highly paid specialists able to use technologies resulting from digitization of financial institu- 
tions, adoption and applying new ICT and Al technologies by them, as well as by clients and society in general.

Recently conducted research have some limitations and it is worth continuing using more carefully selected research methods, such as: qualitative, quantitative and mixed, which will increase the objectivity and credibility of formulated research conclusions. Future study should be multifaceted and cover a wide spectrum of issues related to human capital management in financial institutions. It would be interesting to identify other effective research methods particularly useful for study in this field.

\section{REFERENCES}

Acemoglu, D., \& Restrepo, P. (2016). The Race Between Machine and Man: Implications of Technology for Growth, Factor Shares and Employment.No. 22252. National Bureau of Economic Research.

Autor, D. (2015). Why are there still so many jobs? The history and future of workplace automation. The Journal of Economic Perspectives, 29(3), 3-30.

Becker, G. (2009). Human Capital A Theoretical and Empirical Analysis, with Special Reference to Education. University of Chicago Press.

Bosio, G., \&Cristini, A. (2018). Is the Nature of Jobs Changing? The Role of Technological Progress and Structural Change in the Labour Market. In G. Bosio, T. Minola, F. Origo, S. Tomelleri (Eds.), Rethinking Entrepreneurial Human Capital. The Role of Innovation and Collaboration (pp. 1541). Springer.

Bryl, Ł., \&Truskolaski, S. (2017). Human Capital Reporting and Its Determinants by Polish and German Publicly Listed Companies. Entrepreneurial Business and Economics Review, 5(2), 195-210.

Buzavaite, M., \&Korsakiene, R. (2019). Human Capital and the Internationalisation of SMEs: A Systemic Literature Review. Entrepreneurial Business and Economics Review, 7(3), 125-142.

Central Statistical Office. (2017). Labour Costs in the National Economy in 2016. Central Statistical Office Warsaw.

Clarke, T., \&Gholamshahi, S. (2018). Developing Human Capital for Knowledge Based Economies. In T. Clarke \& K. Lee (Eds.) Innovation in the Asia Pacific (pp.247-270).Springer.

Danvila-del-Valle, I., Estévez-Mendoza, C., \& Lara, F. J. (2019). Human resources training: A bibliometric analysis. Journal of Business Research, 101, 627-636.

Dumay, J. (2016). A critical reflection on the future of intellectual capital: from reporting to disclosure. Journal of Intellectual Capital, 17(1), 168-184.

Eurostat. (2019). Participation in education and training. Adult learning statistics: tables and figures. https://ec.europa.eu/eurostat/cache/metadata/en/trng_Ifs_4w0_esms.htm on May 10, 2020.

European Commission.(2020).Shaping Europe's digital future, Communication from the Commission to the European Parliament, the Council, the European Economic and Social Committee and the Committee of the Regions, Brussels. https://ec.europa.eu/info/sites/info/files/communicationshaping-europes-digital-future-feb2020_en_3.pdf on July 15, 2020.

Garrigos-Simon, F. J., Botella-Carrubi, M. D., \& Gonzalez-Cruz, T. F. (2018). Social Capital, Human Capital, and Sustainability: A Bibliometric and Visualization Analysis. Sustainability 10(12), 4751.

Garza-Rodriguez, J., Almeida-Velasco, N., Gonzalez-Morales, S., \& Leal-Ornelas, A.P. (2018). The Impact of Human Capital on Economic Growth: The Case of Mexico. Journal of the Knowledge Economy, October, 660-675. 
Goldin, C. (2016). Human Capital. In Handbook of Cliometrics, Heidelberg (pp. 55-86). Springer Verlag.

Griffin, R.W. (2018). Fundamentals of Management. Cengage Learning.

Grzeszczyk, T. A. (2017). Costs of Human Capital Development in Financial Institutions (in Polish: Kosztyrozwojukapitałuludzkiego w instytucjachfinansowych). In: M.A. Paszkowicz et al. (ed.), Człowiek - Spoleczenstwo - Gospodarka. Problemy zatrudnienia w organizacjach (pp. 99108).Zielona Góra: Wydawnictwo Naukowe Polskiego Towarzystwa Profesjologicznego, Uniwersytet Zielonogorski.

Hafizi, M.A., \& Zawiyah, M.Y. (2009). Knowledge-based banking: The bankers' experience on OKS (Online Knowledge Sharing). International Journal of Business and Management, 4(2), 31-35.

Haris, M., Yao, H., Tariq, G., Malik, A., \& Javaid, H.M. (2019). Intellectual Capital Performance and Profitability of Banks: Evidence from Pakistan. Journal of Risk and Financial Management, 12, 56, 1-26.

Joshi, M., Cahill, D.,\& Sidhu, J. (2010). Intellectual capital performance in the banking sector: An Assessment of Australian Owned Banks. Journal of Human Resource Costing Accounting, 14, 151-170.

Khan, N., Ahmad, N., Iqbal, N., \& Haider, N. (2014). Relationship of Training and Education with Employee Performance in Financial Institutions. International Letters of Social and Humanistic Sciences, 30(2), 150-156.

Kuzkin, Y., Cherkashyna, T., Nebaba, N., \& Kuchmacz, B. (2019). Economic growth of the country and national intellectual capital (evidence from the post-socialist countries of the central and eastern Europe). Problems and Perspectives in Management, 17(1), 348-359.

Mansion, S.E., \& Bausch, A. (2019). Intangible assets and SMEs' export behavior: a meta-analytical perspective.Small Business Economics. June, 1-34.

Mavridis, D.G. (2004). The Intellectual Capital Performance of the Japanese Banking Sector. Journal of Intellectual Capital, 5(1), 92-115.

Osranek, R., \& Zink, K.J. (2014). Corporate Human Capital and Social Sustainability of Human Resources. In I.Ehnert, W. Harry, \& K. Zink (Eds.) Sustainability and Human Resource Management. CSR, Sustainability, Ethics \& Governance (pp. 105-126). Springer.

Saunders, A.,\& Cornett, M. M. (2007). Financial Institutions Management: A Risk Management Approach. McGraw-Hill/Irwin.

Shih, K.H., Chang, C.J., \& Lin, B. (2010). Assessing Knowledge Creation and Intellectual Capital in Banking Industry. Journal of Intellectual Capital, 11, 74-89.

Statistics Poland. (2019). Banks' financial results in 2018(in Polish: Wyniki finansowe banków w 2018 r. Warsaw, from https://stat.gov.pl/download/gfx/portalinformacyjny/pl/default aktualnosci/5503/5/23/1/wyniki_finansowe_bankow_w_2018_r.pdf on May 10, 2020.

Subramaniam, M., \&Youndt, M. A. (2005). The influence of intellectual capital on the types of innovative capabilities. Academy of Management Journal, 48(3), 450-463.

Yao, H., Haris, M., Tariq, G., Javaid, H.M., \& Khan, M.A.S. (2019). Intellectual Capital, Profitability, and Productivity: Evidence from Pakistani Financial Institutions. Sustainability, July, 11(14), 1-30. 


\section{Author}

\section{Tadeusz A. Grzeszczyk}

Associate professor in Faculty of Management at Warsaw University of Technology, conducts scientific and didactic activity regarding IT and Al project management. His interests and research work also include methodology of management sciences and the use of Al methods in decision support. Correspondence to: Assoc. Prof. Tadeusz A. Grzeszczyk, PhD, Warsaw University of Technology, Faculty of Management, ul. Narbutta 85, 02-524 Warsaw, Poland, e-mail: tadeusz.grzeszczyk@pw.edu.pl

ORCID (i) http://orcid.org/0000-0002-4898-1931

\section{Acknowledgements and Financial Disclosure}

The author would like to thank the anonymous reviewers for their scrupulous reading of the manuscript, constructive critiques and mindful comments, which allowed to increase the value of this paper.

\section{Copyright and License}

(®) (1) $\odot$

This article is published under the terms of the Creative Commons

Attribution - NoDerivs (CC BY-ND 4.0) License

http://creativecommons.org/licenses/by-nd/4.0/

Published by Cracow University of Economics - Krakow, Poland

The journal is co-financed in the years $2019-2020$ by the Ministry of Science and Higher Education of the Republic of Poland in the framework of ministerial programme "Support for Scientific Journals" (WCN) on the basis of contract no. 238/WCN/2019/1 concluded on 15 August 2019. 
